Article

\title{
Neuroprotective and Cytotoxic Phthalides from Angelicae Sinensis Radix
}

\author{
Wenxia Gong ${ }^{1}$, Yuzhi Zhou ${ }^{1, *}$, Xiao Li ${ }^{1}$, Xiaoxia Gao ${ }^{1}$, Junsheng Tian ${ }^{1}$, Xuemei Qin ${ }^{1, *}$ \\ and Guanhua Du ${ }^{1,2}$ \\ 1 Modern Research Center for Traditional Chinese Medicine, Shanxi University, No.92, Wucheng Road, \\ Taiyuan 030006, China; 18835126271@163.com (W.G.); lixiaoedu@126.com (X.L.); \\ gaoxiaoxia@sxu.edu.cn (X.G.); jstian@sxu.edu.cn (J.T.); dugh@imm.ac.cn (G.D.) \\ 2 Institute of Materia Medica, Chinese Academy of Medical Sciences \& Peking Union Medical College, \\ Beijing 100050, China \\ * Correspondence: zhouyuzhi@sxu.edu.cn (Y.Z.); qinxm@sxu.edu.cn (X.Q.); \\ Tel./Fax: +86-351-701-1202 (Y.Z. \& X.Q.)
}

Academic Editor: Nancy D. Turner

Received: 8 March 2016; Accepted: 21 April 2016; Published: 26 April 2016

\begin{abstract}
Seven phthalides, including a new dimeric one named tokinolide C (7), were isolated from Angelicae Sinensis Radix and characterized. The structures of these compounds were elucidated on the basis of comprehensive analysis of spectroscopic data and comparison with literature data. All of the compounds were evaluated for their cytotoxic activities against the A549, HCT-8, and HepG2 cancer cell lines. Riligustilide (4) showed cytotoxicity against three cancer cell lines, with $\mathrm{IC}_{50}$ values of $13.82,6.79$, and $7.92 \mu \mathrm{M}$, respectively. Tokinolide A (6) and tokinolide C (6) exerted low cytotoxicity in these cancer cell lines, while the remaining compounds were inactive. Flow cytometry analysis was employed to evaluate the possible mechanism of cytotoxic action of riligustilide (4). We observed that compound 4 was able to arrest the cell cycle in the G1, S phases and induce apoptosis in a time-dependent manner in HCT-8 cell lines. In addition, these compounds were evaluated for neuroprotective effect against SH-SY5Y cells injured by glutamate. The result showed that ligustilide (1), Z-butylidenephthalide (3) and tokinolide A (6) exhibited significant neuroprotective effects.
\end{abstract}

Keywords: phthalides; Angelicae Sinensis Radix; cytotoxicity activity; flow cytometry; neuroprotective effect

\section{Introduction}

The roots of $A$. sinensis (Oliv.) Diels, also known in Chinese as Dang Gui, a well-known herb belonging to the Umbelliferae family, has been used for more than 2000 years in China. Their ability to produce structurally diverse and biologically significant monomeric and dimeric phthalide metabolites is well documented [1,2]. Previous pharmacological activity studies revealed that these compounds display anti-proliferative [3,4], anti-inflammatory [5-7], anti-thrombus [8], neuroprotective [9-11], anti-tumor [12,13], and anti-spasmodic effects. In recent years, the bioactivities of these compounds have attracted a great interest and extensive research has been carried out to characterize the molecular mechanism(s) behind their activity. However, the studies on the bioactivities of these compounds have been mainly focused on just the monomeric phthalides. In ongoing research efforts to discover novel and bioactive phthalides from Angelicae Sinensis Radix, seven phthalides including three monomeric phthalides and together with four dimeric phthalides were obtained herein. These phthalides were evaluated for cytotoxicity against the A549 (human lung carcinoma), HCT-8 (human colon carcinoma), and HepG2 (human liver carcinoma) cancer cell lines. The possible mechanism of cytotoxicity action of riligustilide (4) was also evaluated by flow cytometry analysis. Numerous studies 
have reported that glutamate-induced neuronal death is associated with the development of several neurodegenerative diseases including Alzheimer's disease, Parkinson's disease, and amyotrophic lateral sclerosis [14,15] and it had been widely used in the drug research. In this study, we used an in vitro model of Glu-induced excitotoxicity in SH-SY5Y cells to investigate the neuroprotective functions of phthalides. The results revealed that ligustilide (1), Z-butylidenephthalide (3) and tokinolide A (6) could significantly antagonize the neurotoxicity of glutamate, suggesting that these compounds could serve as candidates for potential use in the treatment of neurodegenerative diseases.

\section{Results and Discussion}

\subsection{Isolation, Identification, and Structure Elucidation}

The supercritical fluid $\mathrm{CO}_{2}$ extract was subjected to successive column chromatography (CC) on silica gel $\left(\mathrm{SiO}_{2}\right)$ and Sephadex LH-20 gel columns, and to reversed-phase HPLC, which led to the isolation of seven monomeric and dimeric phthalides, including a new compound, named tokinolide $C$ (Figure 1). Among these compounds, five known compounds were identified as ligustilide (1) [16], E-butylidenephthalide (2) [17], Z-butylidenephthalide (3) [17], riligustilide (4) [18], cis-Z,Z'-3a. 7a',7a. 3a'-dihydroxyligustilide (5) [19] by ${ }^{1} \mathrm{H}-\mathrm{NMR}$, and ${ }^{13} \mathrm{C}-\mathrm{NMR}$ spectroscopic data comparison with the corresponding literature data. The structures of the new compound (7) and tokinolide A (6) were elucidated on the basis of spectroscopic data, and their proposed structures were supported by analysis of the corresponding HMQC, HMBC spectra. The relative configuration of 7 was assigned by a NOESY experiment. Models of the molecule of 7 were optimized by MM2 energy-minimized three-dimensional molecular mechanics using Chem 3D Ultra 9.0.

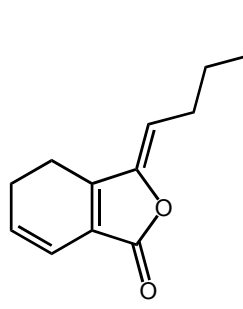

1<smiles>CCC/C=C1\OC(=O)c2ccccc21</smiles>

2<smiles>CCC/C=C1\OC(=O)c2ccccc21</smiles>

3<smiles>CC/C=C1\OC(=O)C2=C1CCC1C2CCC12CCCCC2</smiles>

4

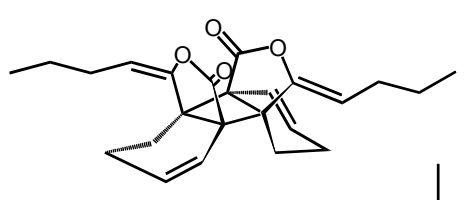

5

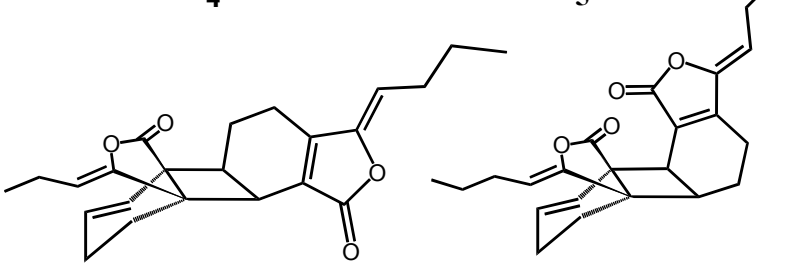

6

7

Figure 1. Chemical structures of the isolated compounds 1-7.

Compound 6 was isolated as a pale yellow oil. The structure were confirmed by ${ }^{1} \mathrm{H}-\mathrm{NMR}$ and ${ }^{13}$ C-NMR spectroscopic data. The HSQC, HMBC experiments allowed for the full assignment of the NMR signals of $\mathbf{6}$. The ${ }^{1} \mathrm{H}-\mathrm{NMR}$ data (Table 1 ) exhibited signals corresponding to the presence of 
four olefinic protons, two methines and two methyl groups. Analysis of the ${ }^{13} \mathrm{C}-\mathrm{NMR}$ spectra showed that compound 6 possessed twenty-four carbon resonances including two carbonyls, eight olefinic carbons, two methyls. Bidirectional HMBC correlations, HSQC correlations, ${ }^{1} \mathrm{H}-\mathrm{NMR}$ splitting patterns and $\delta{ }^{1} \mathrm{H}$ - and ${ }^{13} \mathrm{C}$-values established the presence of two propyl groups between C-9 (9') and C-11 $\left(11^{\prime}\right)$. The olefin proton $\mathrm{H}-8$ showed HMBC correlations to the methylene $\mathrm{C}-10$ and olefinic carbon C-3,3a. And the olefin proton $\mathrm{H}-8^{\prime}$ showed $\mathrm{HMBC}$ correlations to the methylene $\mathrm{C}-10^{\prime}$, olefinic carbon C-3' and quaternary carbon $3 \mathrm{a}^{\prime}$. The olefin proton $\mathrm{H}-6^{\prime}, \mathrm{H}-\mathrm{7}^{\prime}$ respectively exhibited HMBC cross peaks with C-7a' and C-3a' (Figure 2). The methine proton $\mathrm{H}-7$ showed key HMBC correlations with $\mathrm{C}-4^{\prime}$ and C-3a', and the methine proton H-6 showed key HMBC correlations with the carbonyl carbon C-1' and quaternary carbon C-7a', indicating that the two monomer units were linked by 6. 7a'- and 7. 3a'-bonds. Consequently, compound 6 was characterized as tokinolide A (6). Only a few special ${ }^{1} \mathrm{H}-\mathrm{NMR}$ signals of this compound had been previously reported [20]. The ${ }^{1} \mathrm{H}$ - and ${ }^{13} \mathrm{C}-\mathrm{NMR}$ spectroscopic data for the compound are thus completely reported here for the first time.

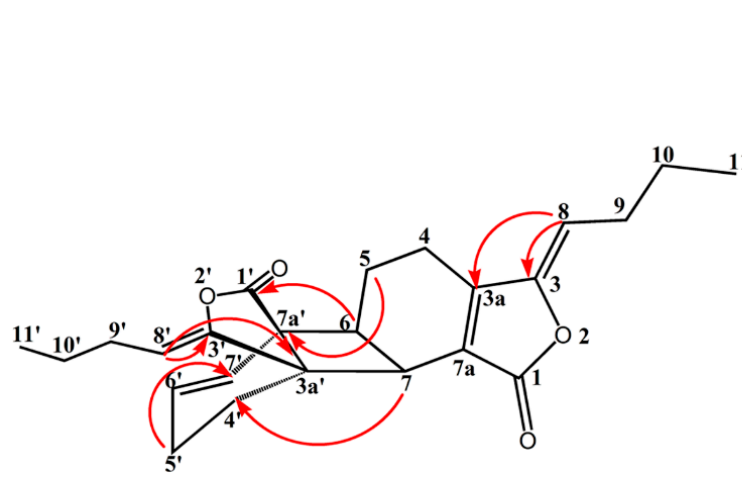

6

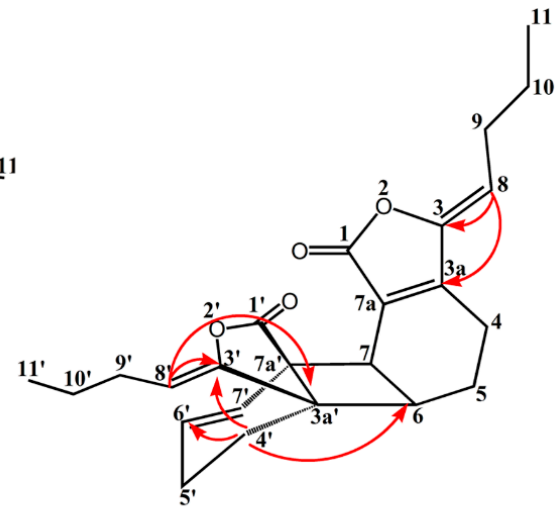

7

Figure 2. Selected HMBC correlations of compound 6 and 7.

Table 1. ${ }^{1} \mathrm{H},{ }^{13} \mathrm{C}$ and $\mathrm{HMBC}$ correlation data for tokinolide $\mathrm{A}(6)^{\mathrm{a}}$.

\begin{tabular}{|c|c|c|c|c|c|c|c|}
\hline Position & $\delta c$, Type & $\delta_{\mathrm{H}},(J$ in $\mathrm{Hz})$ & НМВС & Position & $\delta c$, Type & $\delta_{\mathrm{H}},(J$ in $\mathrm{Hz})$ & НМВС \\
\hline 1 & $169.5, \mathrm{qC}$ & & & $1^{\prime}$ & $175.4, \mathrm{qC}$ & & \\
\hline 3 & $149.0, \mathrm{qC}$ & & & $3^{\prime}$ & $151.4, \mathrm{qC}$ & & \\
\hline $3 a$ & $151.4, \mathrm{qC}$ & & & $3 a^{\prime}$ & $48.2, \mathrm{qC}$ & & \\
\hline 5 & $20.1, \mathrm{CH}_{2}$ & $1.70 \mathrm{~m}, 2.12 \mathrm{~m}$ & $4,6,7,7 a^{\prime}$ & $5^{\prime}$ & $21.0, \mathrm{CH}_{2}$ & $2.10 \mathrm{~m}$ & $7^{\prime}, 3 a^{\prime}, 4^{\prime}, 6^{\prime}$ \\
\hline 6 & $40.2, \mathrm{CH}$ & $2.90 \mathrm{~m}$ & $4,5,7,1^{\prime}, 7 a^{\prime}$ & $6^{\prime}$ & 131.1, CH & $6.11 \mathrm{~m}$ & $4^{\prime}, 5^{\prime}, 7 a^{\prime}$ \\
\hline 7 & $34.1, \mathrm{CH}$ & $3.23 \mathrm{~d}(9.4)$ & $4^{\prime}, 6,3 a, 7 a, 3 a^{\prime}$ & $7^{\prime}$ & $124.6, \mathrm{CH}$ & $6.00 \mathrm{~d}(9.8)$ & $5^{\prime}, 3 a^{\prime}, 7 a^{\prime}$ \\
\hline 8 & $112.1, \mathrm{CH}$ & $5.21 \mathrm{t}(7.9)$ & $3,3 a, 10$ & $8^{\prime}$ & $106.9, \mathrm{CH}$ & $4.66 \mathrm{dd}(7.1,8.3)$ & $3^{\prime}, 3 \mathrm{a}^{\prime}, 10^{\prime}$ \\
\hline 9 & 27.9, $\mathrm{CH}_{2}$ & $2.36 \mathrm{~m}$ & $3,8,10,11$ & $9^{\prime}$ & 27.2, $\mathrm{CH}_{2}$ & $2.08 \mathrm{~m}, 1.90 \mathrm{~m}$ & $3^{\prime}, 8^{\prime}, 10^{\prime}, 11^{\prime}$ \\
\hline 10 & $22.4, \mathrm{CH}_{2}$ & $1.49 \mathrm{~m}$ & $8,9,11$ & $10^{\prime}$ & $22.5, \mathrm{CH}_{2}$ & $1.25 \mathrm{~m}$ & $8^{\prime}, 9^{\prime}, 11^{\prime}$ \\
\hline 11 & $13.7, \mathrm{CH}_{3}$ & 0.95 t (7.4) & 9,10 & $11^{\prime}$ & $13.5, \mathrm{CH}_{3}$ & $0.80,(7.4)$ & $9^{\prime}, 10^{\prime}$ \\
\hline
\end{tabular}

${ }^{a}$ Data obtained on a Varian $600 \mathrm{MHz}$ instrument in $\mathrm{CDCl}_{3}$.

HRESIMS of compound 7 gave an $[\mathrm{M}+\mathrm{H}]^{+}$peak at $m / z 381.2057$, an $[\mathrm{M}+\mathrm{Na}]^{+}$one at $m / z$ 403.1881 and an $[2 \mathrm{M}+\mathrm{Na}]^{+}$one at $m / z$ 783.3898, suggesting a molecular formula of $\mathrm{C}_{24} \mathrm{H}_{28} \mathrm{O}_{4}$. The IR spectrum suggested the existence of lactone $\left(1760 \mathrm{~cm}^{-1}\right)$ and cyclohexene groups $\left(1700 \mathrm{~cm}^{-1}\right)$. The UV spectrum showed an absorption maximum at $280 \mathrm{~nm}$. Comparison of the ${ }^{1} \mathrm{H}$ - and ${ }^{13} \mathrm{C}-\mathrm{NMR}$ data of 7 (Table 2) with those of 6 indicated that they had the similar overall structures. The methylene proton H-4' showed key HMBC correlations with C-6 (Figure 2). NOE correlations between H-4' and $\mathrm{H}-5 / \mathrm{H}-6$ were observed (Figure 3). The above results suggested that the two monomer units were linked by 6.3a'- and 7.7a'-bonds. The relative configuration of 7 was assigned by the NOESY experiment combined with MM2 energy-minimized three-dimensional molecular modeling. The NOE 
correlations of $\mathrm{H}-4$ with $\mathrm{H}-8$, and $\mathrm{H}-8^{\prime}$ with $\mathrm{H}-4^{\prime} / \mathrm{H}-5^{\prime}$ established that they are on the same face of the molecule. Additional NOEs were observed between $\mathrm{H}-4^{\prime}$ and $\mathrm{H}-5 / \mathrm{H}-6$, and also between $\mathrm{H}-7^{\prime}$ and $\mathrm{H}-5 / \mathrm{H}-6$, indicating that the protons at C-4', C-7', C-5 and C-6 were on the same side of the ring system. Furthermore, the NOE correlations of H-8/H-4 and H-8' /H-4' suggested a $3 \mathrm{Z}, 3^{\prime}$ Z-configuration for the double bonds. Thus, compound 7 was elucidated with a structure as shown in Figure 1 and assigned as tokinolide C (7).

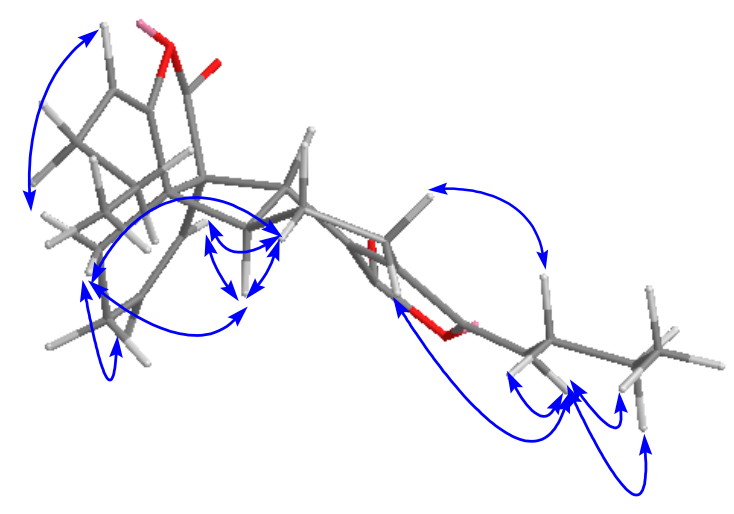

Figure 3. Key NOE correlations for compound 7.

Table 2. ${ }^{1} \mathrm{H},{ }^{13} \mathrm{C}, \mathrm{HMBC}$ and NOESY correlation data for tokinolide $\mathrm{C}(7)^{\mathrm{a}}$.

\begin{tabular}{|c|c|c|c|c|}
\hline Position & $\delta \mathrm{c}$, Type & $\delta_{\mathrm{H}},(J$ in $\mathrm{Hz})$ & HMBC $(\mathrm{H} \rightarrow \mathrm{C})$ & NOESY \\
\hline 1 & 168.7, qC & & & \\
\hline 3 & $148.9, \mathrm{gC}$ & & & \\
\hline $3 a$ & $153.5, \mathrm{qC}$ & & & \\
\hline 4 & $19.0, \mathrm{CH}_{2}$ & $2.21 \mathrm{~m}, 2.57 \mathrm{~m}$ & $3,5,6,3 a, 7 a$ & 8,9 \\
\hline 5 & $21.9, \mathrm{CH}_{2}$ & $1.98 \mathrm{~m}$ & $6,3 a$ & $6,4^{\prime}$ \\
\hline 6 & $37.1, \mathrm{CH}$ & $2.99 \mathrm{dt}(10.4,8.5)$ & $5,7,3 a^{\prime}$ & $5,4^{\prime}, 7^{\prime}$ \\
\hline 7 & $37.0, \mathrm{CH}$ & $3.39 \mathrm{~d}(8.5)$ & $6,3 a, 7 a, 7 a^{\prime}$ & \\
\hline $7 a$ & $124.5, \mathrm{qC}$ & & & \\
\hline 8 & $112.2, \mathrm{CH}$ & $5.24 \mathrm{t}(7.9)$ & $3,3 a, 10$ & $4,9,10,11$ \\
\hline 9 & $27.2, \mathrm{CH}_{2}$ & $2.37 \mathrm{~m}$ & $3,8,10,11$ & $4,8,10,11$ \\
\hline 10 & $22.34, \mathrm{CH}_{2}$ & $1.51 \mathrm{~m}$ & $8,9,11$ & $8,9,11$ \\
\hline 11 & $13.56, \mathrm{CH}_{3}$ & $0.96 \mathrm{t}(7.4)$ & 9,10 & $8,9,10$ \\
\hline $1^{\prime}$ & $176.9, \mathrm{qC}$ & & & \\
\hline $3^{\prime}$ & $153.4, \mathrm{gC}$ & & & \\
\hline $3 a^{\prime}$ & $48.5, \mathrm{qC}$ & & & \\
\hline $4^{\prime}$ & $24.1, \mathrm{CH}_{2}$ & $1.77 \mathrm{~m}, 1.88 \mathrm{~m}$ & $6,3^{\prime}, 6^{\prime}, 7 a^{\prime}$ & $6^{\prime}, 7^{\prime}, 8^{\prime}, 6,5$ \\
\hline $5^{\prime}$ & $20.6, \mathrm{CH}_{2}$ & $1.86 \mathrm{~m}$ & $3 a^{\prime}, 4^{\prime}, 6^{\prime}$ & $8^{\prime}$ \\
\hline $6^{\prime}$ & $133.8, \mathrm{CH}$ & 6.11 ddd (9.9) & $4^{\prime}, 5^{\prime}, 7 a^{\prime}$ & $4^{\prime}, 7^{\prime}$ \\
\hline $7^{\prime}$ & $121.0, \mathrm{CH}$ & $5.77 \mathrm{dd}(1.7,9.9)$ & $4^{\prime}, 3 a^{\prime}$ & $4^{\prime}, 6,5$ \\
\hline $7 a^{\prime}$ & $48.3, \mathrm{qC}$ & & & \\
\hline $8^{\prime}$ & $103.9, \mathrm{CH}$ & $4.88 \mathrm{t}(7.9)$ & $3^{\prime}, 3 \mathrm{a}^{\prime}, 10^{\prime}$ & $4^{\prime}, 9^{\prime}, 10^{\prime}, 11^{\prime}$ \\
\hline $9^{\prime}$ & $28.0, \mathrm{CH}_{2}$ & $2.18 \mathrm{~m}$ & $3^{\prime}, 8^{\prime}, 10^{\prime}, 11^{\prime}$ & $8^{\prime}, 10^{\prime}, 11^{\prime}$ \\
\hline $10^{\prime}$ & $22.6, \mathrm{CH}_{2}$ & $1.44 \mathrm{~m}$ & $8^{\prime}, 9^{\prime}, 11^{\prime}$ & $8^{\prime}, 9^{\prime}, 11^{\prime}$ \\
\hline $11^{\prime}$ & $13.7, \mathrm{CH}_{3}$ & $0.92 \mathrm{t}(7.4)$ & $9^{\prime}, 10^{\prime}$ & $8^{\prime}, 9^{\prime}, 10^{\prime}$ \\
\hline
\end{tabular}

\subsection{Cytotoxicity Assay}

\subsubsection{Cytotoxic Activity of Compounds}

Seven monomeric and dimeric phthalides isolated from the supercritical fluid $\mathrm{CO}_{2}$ extract of Angelicae Sinensis Radix, were evaluated against three cancer cell lines by MTT assays, and the results are summarized in Table 3. All isolated compounds were evaluated for their cytotoxic activities against the HepG2, HCT-8, and A549 cancer cell lines. After the treatment with compounds for $24 \mathrm{~h}$, riligustilide (4) exhibited activity, with $\mathrm{IC}_{50}$ values ranging from 6.79 to $13.82 \mu \mathrm{M}$, tokinolide 
A (6) showed weak activity with $\mathrm{IC}_{50}$ values ranging from 27.79 to $34.34 \mu \mathrm{M}$, and tokinolide $\mathrm{C}$ (7) showed weak activity with $\mathrm{IC}_{50}$ values ranging from 30.92 to $55.84 \mu \mathrm{M}$ against three cancer cell lines. No cytotoxic activity was observed for $\mathbf{1}-\mathbf{3}$ and $5\left(\mathrm{IC}_{50}>80 \mu \mathrm{M}\right)$.

Table 3. Cytotoxic activities of the compounds against three human cancer lines.

\begin{tabular}{cccc}
\hline \multirow{2}{*}{ Compound } & \multicolumn{3}{c}{$\mathrm{IC}_{\mathbf{5 0}}(\mu \mathrm{M})^{\mathbf{a}}$} \\
\cline { 2 - 4 } & $\mathbf{A 5 4 9}$ & HCT-8 & HepG2 \\
\hline $\mathbf{1}$ & $>80$ & $>80$ & $>80$ \\
$\mathbf{2}$ & $>80$ & $>80$ & $>80$ \\
$\mathbf{3}$ & $>80$ & $>80$ & $>80$ \\
$\mathbf{4}$ & $13.82 \pm 2.23$ & $6.79 \pm 1.14$ & $7.92 \pm 1.38$ \\
$\mathbf{5}$ & $>80$ & $>80$ & $>80$ \\
$\mathbf{6}$ & $47.63 \pm 4.51$ & $55.84 \pm 5.99$ & $30.92 \pm 2.36$ \\
$\mathbf{7}$ & $34.34 \pm 3.80$ & $27.79 \pm 3.42$ & $32.54 \pm 2.69$ \\
Doxorubicin $^{\mathbf{b}}$ & $0.28 \pm 0.05$ & $1.55 \pm 0.45$ & $0.65 \pm 0.11$ \\
\hline
\end{tabular}

Values are the mean \pm S.D. for three separate experiments; ${ }^{\text {a }}$ Compound concentration required to inhibit cell growth by $50 \%$. Cells were treated with test samples $(1-80 \mu \mathrm{M})$ for $24 \mathrm{~h} ;{ }^{\mathrm{b}}$ Doxorubicin was used as positive control, and DMSO was negative control.

\subsubsection{Apoptosis-Inducing Activity}

Riligustilide (RLG, 4), which exhibited potent cytotoxic activities against cancer cells, was next evaluated for its apoptosis-inducing activity. In three cancer cell lines, HCT-8 cells were the most sensitive to treatment with RLG, so they were selected to evaluate the possible mechanism of cytotoxic action of RLG. HCT- 8 cells were incubated with the $10 \mu \mathrm{M}$ test compound for 24 and $48 \mathrm{~h}$, and then the cells were analyzed by means of flow cytometry with annexin V-propidium iodide (PI) double staining.

As shown in Figure 4, the ratio of early apoptotic cells (lower right) was increased after treatment with RLG in HCT-8 cells for $24 \mathrm{~h}$ (15.9\% vs. $2.6 \%$ of control, $p<0.01)$ and $48 \mathrm{~h}(22.9 \%$ vs. $7.8 \%$ of control, $p<0.01)$, and that of late apoptotic cells (upper right) was also increased after $24 \mathrm{~h}(13.5 \%$ vs. $6.4 \%$ of control, $p=0.01)$ and $48 \mathrm{~h}(16.8 \%$ vs. $8.5 \%$ of control, $p=0.02)$. These results demonstrated that the cytotoxic activities of compound RLG against HCT-8 cells is due to inducing apoptotic cell death.

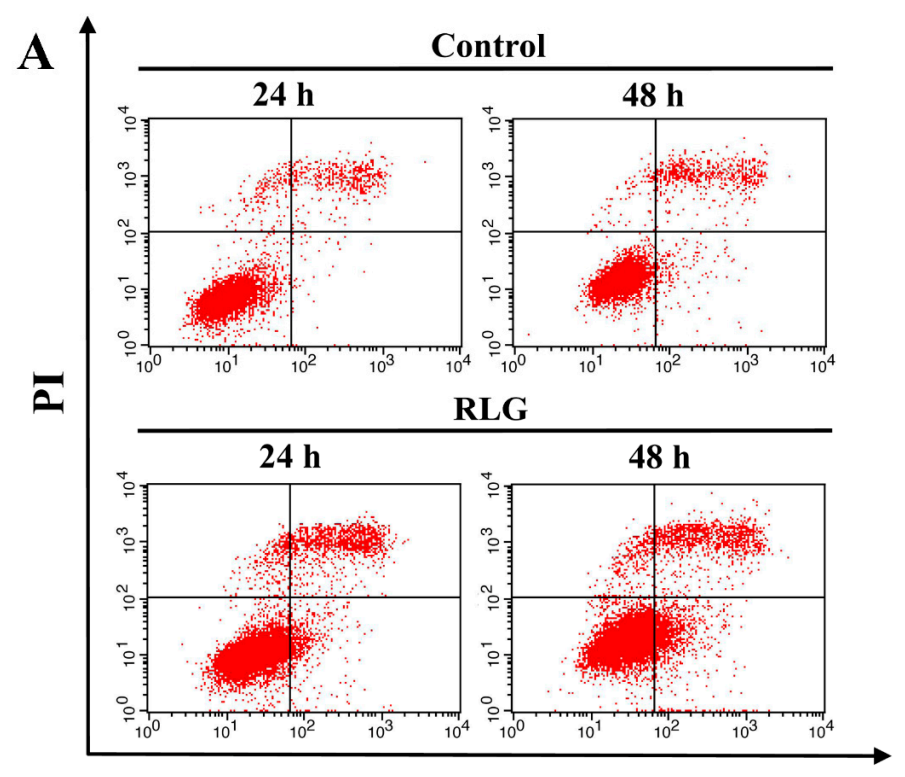

Annexin V-FITC

Figure 4. Cont. 

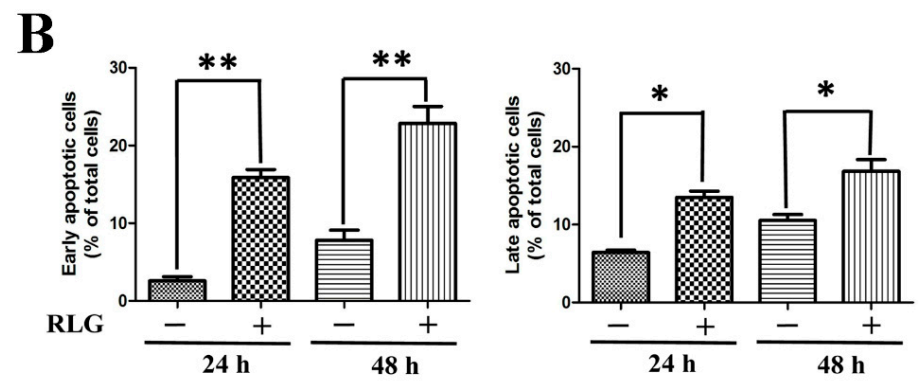

Figure 4. Riligustilide induced apoptosis against HCT-8 cells. (A) Representative apoptotic profile of HCT- 8 cells treated with $10 \mu \mathrm{M}$ RLG for 24 and $48 \mathrm{~h}$ by flow cytometry assay; (B) Statistical analysis of cell apoptotic rate after the treatment of RLG. The data are expressed as the means \pm S.D. of three independent experiments with similar results. Student's $t$-test was used for two group comparison. * $p<0.05$; ** $p<0.01$ vs. the control. "+" represents that $10 \mu \mathrm{M}$ RLG was added, "-" represents control.

\subsubsection{Induction of Cell Cycle Arrest in G1 and S Phase}

To investigate the effects of RLG on the cell cycle, HCT- 8 cells were treated with the $5 \mu \mathrm{M}$ test compound for $24 \mathrm{~h}$ and $48 \mathrm{~h}$, respectively. After an incubation period, the cells were fixed and labeled with propidium iodide. The different phases of the cell cycle were analyzed by flow cytometry.

As can be observed from Figure 5, $24 \mathrm{~h}$ and $48 \mathrm{~h}$ treatment with RLG produced a significant increase of the proportion of cells in G1 phase ( $24 \mathrm{~h}: 71.78 \%$ vs. $54.86 \%$ of control, $p=0.03 ; 48 \mathrm{~h}$ : $75.42 \%$ vs. $60.41 \%$ of control, $p=0.02$ ), along with the reduction of cells in S phase ( $24 \mathrm{h:} 14.89 \%$ vs. $26.99 \%$ of control, $p=0.04 ; 48$ h: $6.63 \%$ vs. $24.03 \%$ of control, $p<0.01$ ), whereas the G2/M remain practically unchanged.

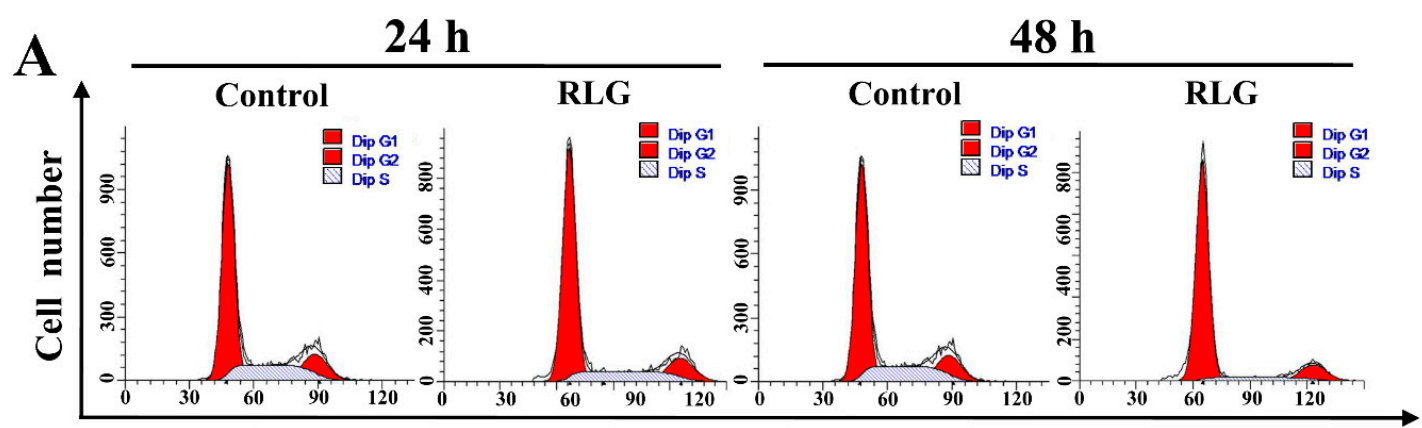

DNA content

B

$24 \mathrm{~h}$

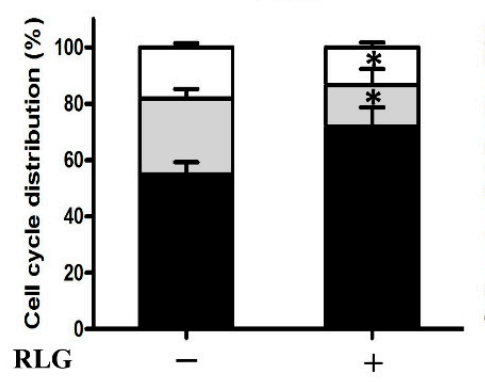

$48 \mathrm{~h}$

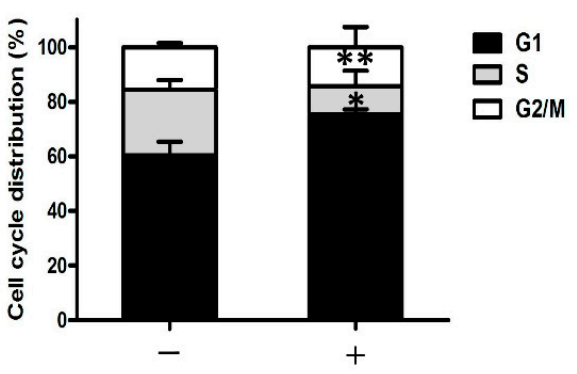

Figure 5. Effect of riligustilide on the cell cycle in HCT-8 cells. Cells were treated with riligustilide $(5 \mu \mathrm{M})$ for 24 and $48 \mathrm{~h}$. Then the cells were fixed and stained with PI to analyze DNA content by flow cytometry. (A) Representative histograms of one cell cycle analysis; (B) DNA content of the gated cells \pm S.D. of three independent experiments. Student's $t$-test was used for two group comparison. * $p<0.05 ;{ }^{* *} p<0.01$ vs. the control. "+" represents that $10 \mu \mathrm{M}$ RLG was added, "-" represents control. 


\subsection{Neuroprotective Effect of Compounds}

Compounds 1-7 were evaluated in vitro for their neuroprotective effects on neuron-like SH-SY5Y cells induced by glutamate, using the MTT method. All of the compounds tested were evaluated and given a corresponding inhibitory (\%) (Table 4). Among the compounds tested, 1, 3 and 6 at $10 \mu \mathrm{M}$ exhibited significant effects against SH-SY5Y cells injured by $20 \mathrm{mM}$ glutamate for $48 \mathrm{~h}$ (1: inhibition 27.1; 3: inhibition 17.0; $\mathbf{6}$ : inhibition 22.2). The effect of compounds $1-7$ on SH-SY5Y cells at $10 \mu \mathrm{M}$ was also evaluated. As shown in Table 5, obvious cell damage effects on cell survival rate was observed when the cells were treated with compound 4 for $48 \mathrm{~h}$, while no significant changes were observed on the viability of cells treated with other compounds. The cytotoxic effect of compound 4 on SH-SY5Y cells at $10 \mu \mathrm{M}$ hampered the assessment of neuroprotection.

Table 4. Survival rate of SH-SY5Y cells injured by glutamate ${ }^{\text {a }}$.

\begin{tabular}{ccc}
\hline Group & Cell Survival Rate (\% of Control) & Inhibition (\% of Model) \\
\hline Control & $100 \pm 9.4$ & \\
Model & $60.2 \pm 2.3^{\# \#}$ & \\
MK-801 $\mathrm{b}$ & $72.8 \pm 5.9^{* *}$ & 31.7 \\
$\mathbf{1}$ & $71.0 \pm 4.1^{* *}$ & 27.2 \\
$\mathbf{2}$ & $63.6 \pm 4.9$ & 8.3 \\
$\mathbf{3}$ & $67.0 \pm 2.1^{*}$ & 17.0 \\
$\mathbf{4}$ & $50.7 \pm 7.0$ & -24.0 \\
$\mathbf{5}$ & $59.3 \pm 4.2$ & -2.4 \\
$\mathbf{6}$ & $69.0 \pm 7.6^{*}$ & 22.2 \\
$\mathbf{7}$ & $62.5 \pm 2.0$ & 5.6 \\
\hline
\end{tabular}

a All the compounds were tested at $10 \mu \mathrm{M} ;{ }^{\# \#} p<0.01$ vs. control; ${ }^{*} p<0.05 ;{ }^{* *} p<0.01$ vs. model group. One-way analysis of variance was used, $n=3{ }^{\mathrm{b}}$ MK-801 was used as positive control.

Table 5. The effects of compounds 1-7 on SH-SY5Y survival rate ${ }^{\text {a }}$.

\begin{tabular}{cc|cc}
\hline Group & Cell Survival Rate (\% of Control) & Group & Cell Survival Rate (\% of Control) \\
\hline Control & $100.0 \pm 10.5$ & $\mathbf{4}$ & $57.4 \pm 4.9^{* *}$ \\
$\mathbf{1}$ & $99.6 \pm 5.9$ & $\mathbf{5}$ & $97.9 \pm 5.2$ \\
$\mathbf{2}$ & $96.6 \pm 2.3$ & $\mathbf{6}$ & $90.9 \pm 14.8$ \\
$\mathbf{3}$ & $100.8 \pm 13.8$ & $\mathbf{7}$ & $93.0 \pm 5.4$ \\
\hline a All the compounds
\end{tabular}

${ }^{a}$ All the compounds were tested at $10 \mu \mathrm{M}$ for $48 \mathrm{~h}$; ${ }^{* *} p<0.01$ vs. control; One-way analysis of variance was used, $n=3$.

\section{Experimental Section}

\subsection{General Procedures}

NMR spectra were recorded on an Avance DRX-600 spectrometer (Bruker, Rheinstetten, Germany) operating at $600\left({ }^{1} \mathrm{H}\right)$ and $150\left({ }^{13} \mathrm{C}\right) \mathrm{MHz}$ with TMS as an internal standard. HRESIMS were ontained on a 1260-6520 QT MS (Agilent, Santa Clara, CA, USA). UV data were recorded on a UV-2450 spectrophotometer (Shimadzu, Kyoto, Japan). IR spectra were measured on a FTIR-8400S spectrometer (Shimadzu, Kyoto, Japan). Column chromatography (CC) supports including silica gel (200-300 mesh, Haiyang Chemical Group Co. Ltd., Qingdao, China), and Sephadex LH-20 gel (25-100 $\mu \mathrm{m}$; Pharmacia Fine Chemicals, Uppsala, Sweden) were also employed. A microplate reader (BMG FLUOStar OPTIMA, Ortenberg, Germany) was used to monitor the growth of the cells. TLC was carried out with glass precoated silica gel GF254 plates (Qingdao Marine Chemical Co. Ltd., Qingdao, China).

\subsection{Plant Material}

Angelica Sinensis Radix was purchased from Shanxi Huayang Pharmaceutical Company (Taiyuan, China) and authenticated by Xue-Mei Qin, Shanxi University, before preparation. A voucher 
specimen was deposited in the Modern Research Center for Traditional Chinese Medicine of Shanxi University, China.

\subsection{Extraction and Isolation}

A supercritical fluid extraction system (HA121-50-01, Huaan Scientific Co. Ltd., Jiangsu, China) was used for the extraction. The parameters, including pressure, temperature, static time, had been optimized based on the yields of extract. Angelica Sinensis Radix (8 kg) was extracted under the following conditions: pressure $20 \mathrm{MP}$; temperature $50^{\circ} \mathrm{C}$; static time $3 \mathrm{~h}$; solvent flow rate $15 \mathrm{~kg} / \mathrm{h}$, and $81.2 \mathrm{~g}$ extract was thus obtained. The extract was separated into 11 fractions (A-K) by silica gel CC, eluting with a step gradient of petroleum ether-ethyl acetate from 100:0 to 0:100 $(v / v)$. Fraction B (3.9 g) was was chromatographed on Sephadex LH-20 gel CC by elution with $\mathrm{CHCl}_{3}-\mathrm{MeOH}(2: 1)$ to afford compound 3 (98 mg). Fraction $\mathrm{C}(4.8 \mathrm{~g})$ was subjected to $\mathrm{SiO}_{2} \mathrm{CC}$ to give six fractions $\left(\mathrm{C}_{1}-\mathrm{C}_{6}\right)$. Fraction $\mathrm{C}_{2}(1.5 \mathrm{~g})$ was chromatographed on Sephadex LH-20 gel CC to afford compounds $\mathbf{1}$ (30.0 mg) and 2 (23.0 mg). Fraction D (2.9 g) was separated using Sephadex LH-20 gel CC by elution with $\mathrm{CHCl}_{3}-\mathrm{MeOH}(2: 1)$ to afford six subfractions $\left(\mathrm{D}_{1}-\mathrm{D}_{6}\right)$. Fraction $\mathrm{D}_{4}(0.8 \mathrm{~g})$ was subjected to HPLC using $80 \%$ aqueous $\mathrm{MeOH}(4 \mathrm{~mL} / \mathrm{min})$ to produce compound $5\left(45.5 \mathrm{mg}, \mathrm{t}_{\mathrm{R}}=9.0 \mathrm{~min}\right)$. Fraction $\mathrm{F}$ $(5.7 \mathrm{~g})$ was further chromatographed on silica gel with an petroleum ether-ethyl acetate solvent system to provide seven subfractions $\left(\mathrm{F}_{1}-\mathrm{F}_{7}\right)$. Fraction $\mathrm{F}_{4}(1.6 \mathrm{~g})$ was purified using Sephadex LH-20 gel CC by elution with $\mathrm{CHCl}_{3}-\mathrm{MeOH}(2: 1)$ to afford four subfractions $\left(\mathrm{F}_{4 \mathrm{~A}}-\mathrm{F}_{4 \mathrm{D}}\right)$. Fraction $\mathrm{F}_{4 \mathrm{C}}(0.7 \mathrm{~g})$ was further purified using $\mathrm{HPLC}\left(\mathrm{MeOH}-\mathrm{H}_{2} \mathrm{O}=70: 30,4 \mathrm{~mL} / \mathrm{min}\right)$ to yield $6\left(30.7 \mathrm{mg}, \mathrm{t}_{\mathrm{R}}=45.59 \mathrm{~min}\right)$ and $7\left(23.8 \mathrm{mg}, \mathrm{t}_{\mathrm{R}}=61.15 \mathrm{~min}\right)$. Fraction $\mathrm{H}(2.5 \mathrm{~g})$ was further chromatographed on silica gel with an petroleum ether-ethyl acetate solvent system to provide ten subfractions $\left(\mathrm{H}_{1}-\mathrm{H}_{10}\right)$. The purification of subfraction $\mathrm{H}_{8}(0.5 \mathrm{~g})$ by Sephadex $\mathrm{LH}-20$ gel CC with $\mathrm{CHCl}_{3}-\mathrm{MeOH}$ (2:1) afforded compound 4 (89.2 mg).

\subsection{Product Characterization}

Tokinolide C (7): pale yellow oil; UV (MeOH) $\lambda_{\max }(\log \varepsilon) 280 \mathrm{~nm}$; IR $v_{\max } 1760,1700 \mathrm{~cm}^{-1}$; For ${ }^{1} \mathrm{H}-\mathrm{NMR}\left(600 \mathrm{MHz}, \mathrm{CDCl}_{3}\right)$ and ${ }^{13} \mathrm{C}-\mathrm{NMR}\left(150 \mathrm{MHz}, \mathrm{CDCl}_{3}\right)$ spectroscopic data, see Table 2; HRESIMS $m / z 381.2057[\mathrm{M}+\mathrm{H}]^{+}$(calcd for $\mathrm{C}_{24} \mathrm{H}_{28} \mathrm{O}_{4}, 381.1980$ ).

\subsection{Cytotoxicity Assay}

\subsubsection{Cell Line Cultures}

The A549 (human lung carcinoma), HCT-8 (human colon carcinoma), Hep G2 (human liver carcinoma) cell lines were obtained from Institute of Materia Medica, Chinese Academy of Medical Sciences and Peking Union Medical College (Beijing, China). Cells were cultured in RPMI 1640 culture medium supplemented with $10 \%$ fetal bovine serum, 100 units $/ \mathrm{mL}$ penicillin, and $100 \mu \mathrm{g} / \mathrm{mL}$ streptomycin at $37^{\circ} \mathrm{C}, 5 \% \mathrm{CO}_{2}$.

\subsubsection{Cell Viability Assay}

Cell viability was determined by the 3-(4,5-dimethylthiazol-2-yl)-2,5-diphenyltetrazolium bromide (MTT) assay. Cells were plated on a 96-well plate at $3 \times 10^{3}$ cells/well and exposed to the test compounds $(1,5,10,20,40,80 \mu \mathrm{M})$ for $24 \mathrm{~h}$. Cultures were also treated with $0.1 \%$ DMSO as the vehicle control. After $24 \mathrm{~h}$ of treatment, $10 \mu \mathrm{L}$ of MTT solution $(5 \mathrm{mg} / \mathrm{mL})$ was added to each well and the plates were incubated for $4 \mathrm{~h}$ at $37^{\circ} \mathrm{C}$. The supernatant was then removed from formazan crystals, and $100 \mu \mathrm{L}$ of DMSO was added to each well. The absorbance at $570 \mathrm{~nm}$ was read using a M200 PRO microplate reader (Tecan). The cell viability was calculated by dividing the mean optical density (OD) of compound containing wells by that of $0.1 \%$ DMSO-control wells [21]. Doxorubicin and DMSO were used as positive and negative controls, respectively. 


\subsubsection{Cell Apoptosis Assay}

The apoptotic cells were measured by flow cytometry using the Annexin V-FITC and PI double staining kit (Nanjing Keygen Biotechnology Co. Ltd., Nanjing, China). Briefly, HCT-8 cells were plated with $1 \times 10^{5}$ cells/well at a 6-well plate and cultured overnight for attachment. Cells were treated with test compound at $10 \mu \mathrm{M}$ for $24 \mathrm{~h}$ and $48 \mathrm{~h}$ respectively. After an incubation period, the cells were collected, washed with PBS, and resuspended in $200 \mu \mathrm{L}$ of binding buffer containing $5 \mu \mathrm{L}$ of Annexin V-FITC and $5 \mu \mathrm{L}$ of PI for $20 \mathrm{~min}$ in the dark. The samples were immediately analyzed by a FACSCalibur flow cytometry (BD Biosciences, San Jose, CA, USA). About 10,000 events were recorded for each sample.

\subsubsection{Cell Cycle Assay}

The DNA content of cells in the G0/G1, S, and G2/M phases can be determined by flow cytometry. Briefly, HCT-8 cells were plated with $1 \times 10^{5}$ cells/well at a 6 -well plate and cultured overnight for attachment. Cells were treated with test compound at $5 \mu \mathrm{M}$ for $24 \mathrm{~h}$ and $48 \mathrm{~h}$ respectively. After an incubation period, the cells were collected, centrifuged and fixed with ice-cold ethanol (70\%) overnight at $4{ }^{\circ} \mathrm{C}$. Cells were centrifuged at $1000 \mathrm{rpm}$ for $5 \mathrm{~min}$ to remove all the ethanol. Each cell pellet were then treated with lysis buffer containing RNAse A and $0.1 \%$ Triton X-100, and then incubated with PI for $30 \mathrm{~min}$ at room temperature in the dark. Then, cells were washed in PBS twice. Samples were analyzed on a FACSCalibur flow cytometer (BD Biosciences). About 20,000 events were recorded for each sample.

\subsection{Neuroprotective Effects Assay}

Neuroprotective effects were assayed in SH-SY5Y cells injured by glutamate as reported previously [22]. SH-SY5Y cells were obtained from Institute of Materia Medica, Chinese Academy of Medical Sciences and Peking Union Medical College. SH-SY5Y cells at a density of $1 \times 10^{4}$ cells per well in 96-well plates were cultured in DMEM media supplemented with $10 \%$ fetal bovine serum. After $24 \mathrm{~h}$ incubation, the medium of model group was changed to basic medium with $20 \mathrm{mM}$ glutamate for $48 \mathrm{~h}$. Tested compounds $(10 \mu \mathrm{M})$ dissolved in dimethyl sulfoxide (DMSO) were added to each well for $>1000$ fold dilution in the model medium at the same time. $N$-Methyl-D-aspartate (NMDA) receptor antagonist dizocilpine (MK-801) was used as positive control. Each sample was tested in triplicate.

Besides, the cytotoxic effect or proliferation effect of these tested compounds on SH-SY5Y cells was also evaluated in the present research. Briefly, cells were plated on a 96-well plate at $1 \times 10^{4}$ cells per well. After $24 \mathrm{~h}$ incubation, the cells were exposed to the test compounds $(10 \mu \mathrm{M})$. Cultures were also treated with $0.1 \% \mathrm{DMSO}$ as the vehicle control. Each sample was tested in triplicate.

After the incubation at $37^{\circ} \mathrm{C}$ in $5 \% \mathrm{CO}_{2}$ for $48 \mathrm{~h}, 10 \mu \mathrm{L}$ of MTT $(5 \mathrm{mg} / \mathrm{mL})$ was added to each well and incubated for another $4 \mathrm{~h}$, then liquid in the wells was removed. DMSO $(100 \mu \mathrm{L})$ was added to each well. The absorbance was recorded on a microplate reader at a wavelength of $570 \mathrm{~nm}$. The survival rate of SH-SY5Y cells was evaluated, and the inhibition (\%) (Table 4) were obtained using the following formula:

$$
\text { Inhibition }(\%)=\left[\left(\mathrm{OD}_{(\text {sample })}-\mathrm{OD}_{(\text {model })}\right) / \mathrm{OD}_{(\text {control })}-\mathrm{OD}_{(\text {model })}\right] \times 100
$$

\subsection{Statistical Analysis}

Data were presented as means \pm S.D. Statistical analysis was performed using the student's $t$-test method or one-ANOVA followed by Dunnett's test when appropriate. Values of $p<0.05$ were considered statistically significant. 


\section{Conclusions}

Seven monomeric and dimeric phthalides, including a new compound, were isolated from the Angelicae Sinensis Radix. Evaluation of their cytotoxic activity against three human cancer cell lines established that riligustilide (4) exhibited potent cytotoxic activity against cancer cells, and this was demonstrated mainly by the induction of apoptosis and cell cycle arrest detected by flow cytometry. In addition, in vitro neuroprotective assays showed that compounds 1, 3 and 6 exhibited significant effects against SH-SY5Y cells injured by glutamate at a concentration of $10 \mu \mathrm{M}$, suggesting that these compounds could serve as candidates for potential application in the treatment of neurodegenerative diseases.

Acknowledgments: This work was financially supported by grants from the Program of International Science and Technology Cooperation of China (No. 2011DFA32630), The National Major Projects of Drug Discovery (No. 2012ZX09103201-035), Program of Science and Technology of Shanxi Province (No. 20140313008-14), and The Construction of the Science and Technology Basic Condition Platform of Shanxi Province (No. 2014091022).

Author Contributions: Guanhua Du and Xuemei Qin conceived and designed the experiments. Wenxia Gong carried out the isolation and identification of compounds. Xuemei Qin and Xiaoxia Gao collected and identified the plant. Xiao Li and Junsheng Tian carried out the in vitro assay. Yuzhi Zhou wrote the paper.

Conflicts of Interest: The authors declare no conflict of interest.

\section{References}

1. Ma, J.P.; Guo, Z.B.; Jin, L.; Li, Y.D. Phytochemical progress made in investigations of Angelica sinensis (Oliv.) Diels. Chin. J. Nat. Med. 2015, 13, 241-249. [CrossRef]

2. Chen, X.P.; Li, W.; Xiao, X.F.; Zhang, L.L.; Liu, C.X. Phytochemical and pharmacological studies on Radix Angelica Sinensis. Chin. J. Nat. Med. 2013, 11, 577-587. [CrossRef] [PubMed]

3. Winnie, L.T.; Chi, H.C.; John, A.R.; Ge, L. Study of the anti-proliferative effects and synergy of phthalides from Angelica sinensis on colon cancer cells. J. Ethnopharmacol. 2008, 120, 36-43.

4. Lee, T.F.; Lin, Y.L.; Huang, Y.T. Studies on antiproliferative effects of phthalides from Ligusticum chuanxiong in hepatic stellate cells. Planta Med. 2007, 73, 527-534. [CrossRef] [PubMed]

5. Chung, J.W.; Choi, R.J.; Seo, E.K.; Nam, J.W.; Dong, M.S.; Shin, E.M.; Guo, L.Y.; Kim, Y.S. Anti-inflammatory effects of (Z)-Ligustilide through suppression of mitogen-activated protein kinases and nuclear factor- $\mathrm{kB}$ activation pathways. Arch. Pharm. Res. 2012, 35, 723-732. [CrossRef] [PubMed]

6. Chou, T.H.; Chen, I.S.; Hwang, T.L.; Wang, T.C.; Lee, T.H.; Cheng, L.Y.; Chang, Y.C.; Cho, J.Y.; Chen, J.J. Phthalides from Pittosporum illicioides var. illicioides with inhibitory activity on superoxide generation and elastase release by neutrophils. J. Nat. Prod. 2008, 71, 1692-1695. [CrossRef] [PubMed]

7. Liu, L.; Ning, Z.Q.; Shan, S.; Zhang, K.; Deng, T.; Lu, X.P.; Cheng, Y.Y. Phthalide lactones from Ligusticum chuanxiong inhibit lipopolysaccharide-induced TNF- $\alpha$ production and TNF- $\alpha$-mediated NF-KB activation. Planta Med. 2005, 71, 808-813. [CrossRef] [PubMed]

8. Zhang, L.; Du, J.R.; Wang, J.; Yu, D.K.; Chen, Y.S.; He, Y.; Wang, C.Y. Z-ligustilide extracted from Radix Angelica Sinensis decreased platelet aggregation induced by ADP ex vivo and arterio-venous shunt thrombosis in vivo in rats. Yakugaku Zasshi 2009, 129, 855-859. [CrossRef] [PubMed]

9. Wei, Q.; Yang, J.B.; Ren, J.; Wang, A.G.; Ji, T.F.; Su, Y.L. Bioactive phthalides from Ligusticum sinense Oliv cv. Chaxiong. Fitoterapia 2014, 93, 226-232. [CrossRef] [PubMed]

10. Qi, H.Y.; Han, Y.F.; Rong, J.H. Potential roles of PI3K/Akt and Nrf2-Keap1 pathways in regulating hormesis of Z-ligustilide in PC12 cells against oxygen and glucose deprivation. Neuropharmacology 2012, 62, 1659-1670. [CrossRef] [PubMed]

11. Peng, B.; Zhao, P.; Lu, Y.P.; Chen, M.M.; Sun, H.; Wu, X.M.; Zhu, L. Z-ligustilide activates the Nrf2/HO-1 pathway and protects against cerebral ischemia-reperfusion injury in vivo and in vitro. Brain Res. 2013, 1520, 168-177. [CrossRef] [PubMed]

12. Liu, P.Y.; Sheu, J.J.; Lin, P.C.; Lin, C.T.; Liu, Y.J.; Ho, L.I.; Chang, L.F.; Wu, W.C.; Chen, S.R.; Chen, J.; et al. Expression of Nur77 induced by an $n$-butylidenephthalide derivative promotes apoptosis and inhibits cell growth in oral squamous cell carcinoma. Investig. New Drugs 2012, 30, 79-89. [CrossRef] [PubMed] 
13. Chiu, S.C.; Chen, S.P.; Huang, S.Y.; Wang, M.J.; Lin, S.Z.; Harn, H.J.; Pang, C.Y. Induction of apoptosis coupled to endoplasmic reticulum stress in human prostate cancer cells by $N$-butylidenephthalide. PLoS ONE 2012, 7, e33742. [CrossRef] [PubMed]

14. Dumont, R.J.; Okonkwo, D.O.; Verma, S.; Hurlbert, R.J.; Boulos, P.T.; Ellegala, D.B.; Dumont, A.S. Acute spinal cord injury, part I: Pathophysiologic mechanisms. Clin. Neuropharmacol. 2001, 24, 254-264. [CrossRef] [PubMed]

15. Lankiewicz, S.; Marc, L.C.; Truc, B.N.; Krohn, A.J.; Poppe, M.; Cole, G.M.; Saido, T.C.; Prehn, J.H. Activation of calpain I converts excitotoxic neuron death into a caspase-independent cell death. J. Biol. Chem. 2000, 275, 17064-17071. [CrossRef] [PubMed]

16. León, A.; Chávez, M.I.; Delgado, G. ${ }^{1} \mathrm{H}$ and DOSY NMR spectroscopy analysis of Ligusticum porteri rhizome extracts. Magn. Reson. Chem. 2011, 49, 469-476. [CrossRef] [PubMed]

17. Roscini, C.; Davies, D.M.; Berry, M.; Orr-Ewing, A.J.; Booker-Milburn, K.I. Product selection through photon flux: Laser-specific lactone synthesis. Angew. Chem. Int. Ed. Engl. 2008, 47, 2283-2286. [CrossRef] [PubMed]

18. Kaouadji, M.; Pachtere, F.D.; Pouget, C.; Chulia, A.J.; Lavaitte, S. Three additional phthalide derivatives, an epoxymonomer and two dimers, from Ligusticum wallichii rhizomes. J. Nat. Prod. 1986, 49, 872-877. [CrossRef]

19. Li, W.; Wu, Y.; Liu, X.; Yan, C.; Liu, D.; Pan, Y.; Yang, G.; Yin, F.; Weng, Z.; Zhao, D.; et al. Antioxidant properties of cis-Z,Z'-3a.7a',7a.3a'-dihydroxy ligustilide on human umbilical vein endothelial cells in vitro. Molecules 2013, 18, 520-534. [CrossRef] [PubMed]

20. Takashi, T.; Masaru, K.; Ko, K.; Hiroshi, M. Studies on the constituents of Umbelliferae plants. XVI. Isolation and structures of three new ligustilide derivatives from Angelica acutiloba. Chem. Pharm. Bull. 1987, 35, $4460-4464$.

21. Mosmann, T. Rapid colorimetric assay for cellular growth and survival: Application to proliferation and cytotoxicity assays. J. Immunol. Methods 1983, 65, 55-63. [CrossRef]

22. Nampoothiri, M.; Reddy, N.D.; John, J.; Kumar, N.; Kutty, N.G.; Rao, C.M. Insulin blocks glutamate-induced neurotoxicity in differentiated SH-SY5Y neuronal cells. Behav. Neurol. 2014, 2014, 674164. [CrossRef] [PubMed]

Sample Availability: Samples of the compounds 1-7 are available from the authors.

(c) 2016 by the authors; licensee MDPI, Basel, Switzerland. This article is an open access article distributed under the terms and conditions of the Creative Commons Attribution (CC-BY) license (http://creativecommons.org/licenses/by/4.0/). 